Articles

\title{
ICT and Online Social Movements for Good Governance in Nigeria
}

\author{
Usman Adekunle \\ Ojedokun \\ Department of Sociology, University of \\ Ibadan, Nigeria \\ Corresponding Author. \\ uaojedokun@gmail.com
}

\begin{abstract}
In Nigeria, the availability of different Internet-enabled social media has led to the emergence of online social movements advocating the principle of good governance in the affairs of the state. In view of this, this paper examined the evolution of online social movements in Nigeria, and the role of ICT in their mobilization for good governance. Resource mobilization theory was employed as the explanatory framework. The paper contends that though online social movements in Nigeria are generally in their embryonic stage, they are, nonetheless, increasingly influencing the three organs of government and shaping public policies in the country.
\end{abstract}

\section{Introduction}

Since its emergence in the 20th century, Information and Communication Technology (ICT) continues to have a landmark impact on human relations and social structures worldwide (Adeyemo, 2010; Ojedokun, 2010). Today, ICT is fast becoming one of the major tools that social movements around the world are adopting to advance their cause(s) (Cardoso and Neto, 2004; Oloo and Kamungi, 2012). In Nigeria, the availability of different Internetenabled social media such as Facebook, Twitter, Hi5, WhatsApp, YouTube, BlackBerry Messenger, MySpace, 2go among others has led to the emergence of online social movements advocating the principle of good governance in the affairs of the state.

The term 'social media' refers to web-based tools and services that allow users to create, share, and search for content and information without having to log on to any specific portal site or portal destination (Bohler and van der Merwe, 2011). To Kaplan and Haelen (2010),

Ojedokun, U. (2016). ICT and Online Social Movements for Good Governance in Nigeria. The Journal of Community Informatics, 12(1), 7-20.

Date submitted: 2014-12-24. Date accepted: 2015-07-10.

Copyright (C), 2016 (the author as stated). Licensed under the Creative Commons Attribution-

NonCommercial-ShareAlike 2.5. Available at: www.ci-journal.net/index.php/ciej/article/view/1187 
they are a group of Internet-based applications that build on the ideological and technological foundations of web 2.0 that allow the creation and exchange of user-generated content. Social media essentially involve the adoption of web-based technologies to transform and broadcast media monologues into social dialogues (Titus-Fannie et al., 2013). Also, it can generally be said that social media integrate different forms of computer-mediated communication (CMC) (Hogan and Quan-Haase, 2010). To Ibrahim (2013), the exposure, feedback, engagement (connecting) and exchange (sharing) that social media platforms create, provide a major change in the understanding of traditional communication. Information flow is no longer considered "one-way street" in which audiences receive messages through the "I communicate-you receive' mantra. Rather, social media integration is seen as an interactive process that enables same-level information exchange among the audience (Gracia, 2011). Social media's social affordance, according to Hogan and Quan-Haase (2010), means that people are employing these tools to interact, share information, communicate, and develop perceptions of their social environment.

The principle of good governance occupies a strategic position in the development trajectory of any nation that cannot be overemphasised. The recognition of this fact is responsible for the continuous clamour for the adoption of good governance in the running of state affairs in different parts of the world. Good governance has been defined in different ways by scholars and international organisations. The World Bank (1989) defines it as a means of exercising power in the management of a nation's economic and social resources for sustainable development. To Odock (2006), good governance is a system of government based on good leadership, respect for the rule of law and due process, the accountability of the political leadership to the electorate, as well as transparency in the operations of government. Ekpu (2009) views it as connoting respect for the rule of law, accountability, transparency, delivery on election promises, and creation of an atmosphere for the flowering of freedom and for the achievement of the greatest good for the greatest number of the people. According to the United Nations Development Programme policy document developed in 1997, good governance is characterised by participation, the rule of law, effectiveness and efficiency, transparency (built on the free flow of information), responsiveness, consensus orientation, equity, accountability, and strategic vision.

Just like in some other countries, different online social movements are among the major forces for good governance in Nigeria. Social movements are any broad social alliances of people who are connected through their shared interest in blocking or effecting social change (Cragun and Cragun, 2006). According to Diani (1992), social movements comprise networks of informal interaction between a plurality of individuals, groups and/or organisations, engaged in a political or cultural conflict on the basis of a shared collective identity. They are one of the principal social forms through which collectivities give voice to their grievances and concerns about the rights, welfare, and well-being of themselves and others by engaging in various types of collective action, such as protesting in the streets, dramatizing their grievances and concerns, and demanding that something be done about them (Snow et al., 2004). Some of the factors identified to have been responsible for the birth of social movements include: feelings of deprivation, social unrest, dissatisfaction, a sense of injustice, ideology or beliefs, social stresses (such as a crisis or cultural lag), resources, organization, and an orientation toward change (Stolley, 2005). Generally, every social movement involves collective action of people who work to enact some type of change they feel would be preferable in the social structure (Stolley, 2005). 
In view of this, the central focus of this paper is to discuss the evolution of online social movements in Nigeria and the role of ICT in their mobilization for good governance in the country. The remainder of the paper is divided into four major sections:

- the relationship between ICT and social movements globally,

- the evolution of online social movement in Nigeria,

- the role of ICT in the campaign of online social movements for good governance in Nigeria, and,

- the major challenges threatening the online activism of online social movements in Nigeria.

\section{ICT and Social Movements' Activities Globally}

Over the last decade, online activism has become increasingly prevalent for sharing information and organizing people to express resistance to dominant organizational elites (Ghobadi and Clegg, 2014). In many countries around the world, ICTs have been used by ordinary citizens and interest groups to demand governance reforms intended to realize the aspirations of the people (Oolo and Kamungi, 2012). Cardoso and Neto (2004) observe that contemporary social movements tend to have in common the assimilation of ICT as an instrument of action and organization. According to them, the Internet is becoming the central axis of action allowing social movements to act globally. ICT and mass media are closely related to social movements and collective action (Speir, 2011). Norris (2001) identifies the major functions served by the Internet in different social movements' activities across the globe, including: e-mail lobbying of political representatives, officials, and elites; networking with related associations and organisations; mobilising organisers, activists and members; fundraising and recruitment; and disseminating messages to multiple audiences. Also, Geser (2001) views the Internet as an ideal facilitative tool for founding, integrating and managing voluntary associations. For Wasserman (2005), the Internet and other ICT tools (such as mobile phones) are valuable tools in the activities of social movements that represent a broad agenda, including social development. Haase-Reed et al. (2007) submit that the success of a social movement relies on public perceptions of the opportunity to refute criticism, counter negative coverage, and deliver their own messages uncontested. The significance of the Internet, according to Salmon et al. (2010), stems from the fact that it defies boundaries, challenges governmental media censorship, and provides an alternative voice to traditional media outlets, which often echo official, governmental policies and views. Meanwhile, it is considered by many scholars as a potential means of extending the working of transnational social movements geographically, organising internationally, building global or regional coalitions with like-minded organisations, mobilising beyond their own constituencies, and spreading information on a global scale independently; thereby, supporting the development of global or transnational public spheres (Kahn and Kellner, 2004; Scott and Street, 2001).

Since the early 1990s, when the Zapatista of Chiapas movement in Mexico first made use of the Internet to protest against the North American Free Trade Agreement (Castells 1997), different global social movements have employed the Internet, and more recently mobile phones, to share information, organize direct action and coordinate activities that confront economic and social injustices spawned by global capitalism (Kahn and Kellner 2004; Wall, 
2007). Also, Internet-based communication technologies provided an important additional resource for social movements in the anti-G8 protest staged in Genoa in 2001 and the antiEuropean Social Forum held in Florence in 2002 (Della Porta and Mosca, 2005). Similarly, the Internet and mobile phones were used to mobilize and organise public protests against repressive rule, corruption, economic failings and other grievances in Tunisia, Egypt, Libya and several other Arab states in the so-called Arab Spring revolution in 2011 (Oloo and Kamungi, 2012). Additionally, Cortright (2007) observes that during the Iraqi antiwar movement, activists used the Internet to communicate, coordinate, and create awareness among decentralized networks which resulted in global protests that brought together about 10 million activists who demonstrated in hundreds of cities worldwide on February 15, 2003. According to Langman (2005), the Internet has also enabled the creation of diverse democratic groups and movements, such as the World Social Forum, which mobilized global justice movements of more than 100,000 diverse activists in Brazil in 2003 and in Mumbai in 2004. The experience of Afghanistan shows that the real benefit of ICT lies not in the provision of technology per se, but in promoting the creation of powerful social and economic networks that improve communication and the exchange of information (Oolo and Kamungi, 2012).

\section{Theoretical Framework}

\section{Resource Mobilization Theory}

Resource mobilization theory provides the theoretical anchorage for this paper. This theory gained prominence throughout the 1970s and 1980s. Resource mobilization theory sees social movements as rational social institutions, created and populated by social actors with certain goals. It stresses the importance of human and material resources and rational planning as the sources of social movements and the basis for their success (Gamson et al., 1982; Oberschall, 1973). According to the theory, resources such as time, money, organizational skills and certain social or political opportunities are critical to the success of social movements. It puts resources at the centre of the analysis of social movement and stresses movement members' ability to acquire resources and mobilize people towards accomplishing a particular goal(s). It makes clear that both the availability of resources and actors' efficacy in using them effectively are central to social movements' activities. In the context of Nigeria, online social movements are essentially exploiting the availability of different Internet-enabled social media platforms to advocate the principle of good governance in state affairs.

\section{Evolution of Online Social Movements in Nigeria}

The evolution of online social movements in Nigeria is not solely propelled by the availability of Internet-enabled social networking media. Rather, their trajectory is firmly rooted in the foundation laid by the conventional social movements and different civil society organisations fighting for justice and fairness in the actions of the government at various levels. Indeed, from the period of British colonial rule, different groups in Nigeria have come together to form social movements with the purpose of stimulating change in one area of social life or the other. For instance, in 1929, some Igbo women in South Eastern Nigeria confronted the British colonial government in protest against rumoured plans for 'per capita taxation' of women. The protest is generally referred to as the Aba women riot. Similarly, 
some farmers in South Western Nigeria formed the Agbekoya movement in 1968 to revolt against the then military government's decision to increase tax, and the subsequent arrests of defaulters by law enforcement agents (Ibeanu and Momoh, 2008). Additionally, in the SouthSouth region of the country, different social movements have sprung up to protest about environmental degradation and the general state of underdevelopment of the area, in spite of the fact that it is the hub of crude oil exploration which is essentially the mainstay of Nigeria's economy. Apart from this, civil society organisations like the Campaign for Democracy (CD), Civil Liberties Organizations (CLO), Committee for the Defense of Human Rights (CDHR), Transition Monitoring Group (TMG), Nigeria Labour Congress (NLC), National Association of Nigerian Students (NANS), Academic Staff Union of Universities (ASUU) have been at the forefront of championing the cause for democratic governance and fairness in public affairs (Akanle et al., 2014). The birth of online social movements in Nigeria is closely linked to the large-scale adoption of Internet-enabled social networking media among Nigerians. Although computer-mediated communication and the Internet revolution generally began in the country in the late $1990 \mathrm{~s}$, online social movements have begun springing up unconsciously since 2007 when Facebook started gaining popularity among Nigerians. Today, with the proliferation of varieties of Internet-enabled social media platforms such as Twitter, Myspace, Hi5, Blackberry Messenger, 2go, amongst others, different online social movements aimed at mobilizing for good governance in public affairs have consciously emerged. In Nigeria, a number of online social movements have developed with the goal of drawing national and international attentions to social, economic and political injustices in the country. Notable online social movements which have emerged in recent times include: Occupy Nigeria Movement, Change Movement, Bring Back Our Girls Movement, Movement for Democratic Change and Peoples' Rights (MDCPR), Social Movement for Change (SMC), Transform Nigeria Movement, amongst others.

\section{Online Social Movements and Good Governance in Nigeria}

Although the modus operandi of online social movements in Nigeria in terms of online activism and types of social media platforms favoured for public mobilization is similar to what might be found elsewhere, Nigeria's situation is unique in its own right. Unlike what obtained in some other countries, particularly in Africa where ICT-driven mass mobilisation led to violent demonstrations that ousted Presidents Zine El-Abidine Ben Ali (Tunisia) Muammar Gaddafi (Libya), and Hosni Mubarak (Egypt), online activism of social movements in Nigeria has never resulted in any violent physical protest or demonstration against the Nigerian government. Rather, the series of virtual and peaceful protests embarked upon by Nigerians online over time culminated in the defeat of the immediate past Nigerian President, Goodluck Jonathan, who re-contested for the office of the Nigerian President in the March 28, 2015 general election under the platform of the Peoples' Democratic Party (PDP), the dominant party that had been at the helm of the affairs since 1999 when the Nigeria's fourth republic began. It is important to point out that the former ruling party, PDP, had been persistently accused by Nigerians of running an elitist government that has legitimised corruption and engendered poverty in Nigeria (Akinkuotu, 2015; Gbadebo, 2014). Indeed, it is a widely shared belief that the victory of Muhammadu Buhari (of the All Progressive Congress opposition party, ) in the recently held presidential election, might not have been possible without the online activities of different online social movements. Social media platforms were actively utilised to keep Nigerians and members of the international 
community up-to-date on the result of the 2015 general elections in Nigeria (Nwabasha, 2015; Oseni, 2015).

Also, unlike its counterparts in Iran, Syria, and Egypt that attempted to clamp down on the utilisation of social media platforms by their citizens in the face of pressure and strong criticism by online social movements calling for change in public affairs (Stepanova, 2011; Stanko, 2013), the Nigerian Government has over time been tolerant and/or accommodating to online activism, and occasional physical protests, that are often embarked upon by online social movements questioning the action or inaction of government and some of its key officials in the administration of state affairs. Although law enforcement agents (especially personnel of the Nigeria Police Force) are often on guard to monitor the physical protests organised by online social movements to forestall a breakdown of law and order, they rarely engage in intimidation or physical confrontation with protesting online social movement activists.

Generally, the role of Information and Communication Technology (ICT) in online social movements' activities for the entrenchment of the principle of good governance in Nigeria cannot be overemphasized. Though these movements are generally in their embryonic stage, the prevailing state of affairs in Nigeria shows that they are not only increasingly influencing key decisions of the three organs of government, but they are also shaping public policies in the country. One major way through which ICT is aiding online social movements in promoting the tenets of good governance is that it creates several avenues through which members of the general public can easily bring vital information to the attention of the government and other concerned stakeholders in the country.

Through the high level information dissemination capacity of ICT, online social movements in Nigeria are gradually aiding management's effectiveness and efficiency in affairs of the state. For instance, different online social movements in the country played a critical role in inundating the Federal Government of Nigeria with information on the 'cash for slot scam', the practice whereby unemployed graduates seeking employment in government agencies are asked to pay certain amount of money to some top officials and/or agents of their would-beemployers which is rife in government-owned agencies. The response of the Nigerian Government to this information was the scrapping of online sale of application forms to job seekers in government agencies (Nzeshi et al., 2013). In a related development, online social movements actively adopted Internet-enabled social media, particularly Facebook and Twitter, to protest the poor handling of recruitment exercise into the Nigeria Immigration Service by a former Minister of Interior, Abba Moro, which led to the death of 16 applicants and injury of many others (Ojeme, 2014; Soriwei and Adepegba, 2014). The virtual protests of several online social movements later culminated in physical demonstrations which eventually forced the government to compensate the bereaved and those that were injured. The government not only cancelled the recruitment exercise, but also promised to design an all inclusive and effective procedure in the near future.

Similarly, online social movements are utilizing ICT devices to promote respect for the rule of law and human rights in Nigeria. ICT-enabled social platforms such as Facebook, Twitter, Youtube (amongst others) constitute invaluable resources through which online social movements not only canvass respect for the rule of law, but also expose various social ills in society. In 2013, different online social movements and many human right activists/ 
organizations in Nigeria mounted pressure on the Taraba State House of Assembly to uphold constitutional provision, by approving the continuation in office of the deputy governor of the state, Alhaji Garba Umar, as the acting governor; this was amid a crisis generated by the hasty return of Governor Danbaba Suntai to Nigeria after spending several months abroad where he went to receive treatment for the injury that he sustained from a plane crash which occurred in late 2012 ( Owuamanam, 2013).

Though Gov. Suntai's loyalists wanted him to return to office at all costs, in spite of the fact that he was medically unfit to do so, the State's House of Assembly followed the due process of the law (The Nation, 2013; Vanguard, 2013). The online social movements in Nigeria played a crucial role in resolving this particular crisis. Another example that readily comes to mind in this context is the video of the extra-judicial killing of four students of the University of Port Harcourt, known as ' the Aluu 4' which went viral on the Internet in 2012 (Akasike, 2012). Also, the case of a purported Abia State female student who was gang-raped in September, 2011 was first brought to the knowledge of the general public through the recorded video of the episode that was released onto the Internet (Ugwu, 2013). Recently, in March 2014, the video of a policeman who brutally maltreated two women at gun-point in Lagos State was uploaded onto the Internet (Ogala, 2014). In each of these highlighted cases, online social movements used different online social networking platforms to seek redress for the victims of the incidents. Indeed, the ability to be spontaneous and mobilise under serious constraints has been observed to be one of the most important benefits that social media adds to the effectiveness of contemporary social movements (Petras, 2011; Wilson, 2012).

Furthermore, online social movements in Nigeria are actively adopting different ICT tools to contribute to, and deliberate on public policies formulated by different tiers of government in the country. As a result of online public debates facilitated by ICT resources, government and other concerned stakeholders are continuously getting feedback on their policies and are increasingly taking citizens' concerns into consideration before implementation. For example, online social movements were at the forefront of the protest against the Federal Government's removal of fuel subsidy in January, 2012. Notable among the online social movements in this instance was the Occupy Nigeria movement. Adebayo (2014) and Akanle et al. (2013) assert that of all the protests that were staged by different organisations in Nigeria, none was as coordinated and massive as the protest of January 2012 in which the Internet was effectively exploited to mobilise protesters against fuel subsidy in Nigeria, and in London, Brussels, Washington and other places, in solidarity. The enormity of the protest orchestrated by online social movements forced the Nigerian Government to modify this particular policy. In addition, various online social movements in Nigeria significantly influenced the decision of the Federal Government of Nigeria to pass into law, the Anti-Gay Bill, which proscribed the practice of same-sex relationships in the country (Akhigbe, 2014).

Equally, the virtual and physical protests of online social movements were instrumental in the Nigerian government reaching a mutual agreement with members of the Academic Staff Union of Universities (ASUU) which eventually ended their six-months old nationwide strike between June and December, 2013. Roberts (2011) has equally asserted that Internet offers a better medium for the creation of a public sphere in which a truly democratic form of political debate can take place. The interactive features of digital ICT opens up unprecedented opportunities for more inclusive public engagement in the deliberation of policy problems 
(Ibrahim, 2013). These open fora for debates and exchange of diverse views among all levels of society encourage an informed citizenry (Shifter and Caivano, 2009).

Online social movements are employing ICT devices to demand transparency and accountability in the administration of government in Nigeria. Internet-enabled social media are aggressively being adopted by different online social movements to protest perceived sharp or corrupt practices of public officials in the discharge of their duties. In 2013, different online social movements in Nigeria protested the mismanagement of public funds by a former Minister of Aviation, Stella Oduah in the purchase of two bullet-proof BMW cars at an inflated rate of N225 million (The Punch, 2014). Different protests engineered through Internet-enabled social media forced the Federal Government to set up a Presidential Probe Panel which later indicted her. In a related development, a series of protests by online social movements influenced the decision of the Judiciary to call for the retrial of an Assistant Director in the Police Pension Office, John Yakubu who was sentenced to two years imprisonment or pay N750, 000 fine by a Justice of the Federal Capital Territory High Court, Justice Mohammed Talba, for conniving with some other officers to defraud the Police Pension Office and Pensioners of N27.2 billion (Latinwo, 2013). ICT tools provide checks and balances and foster a climate of accountability in the society which helps to expose grand and petty corruption in public spaces, inefficiency in public service delivery and structural challenges to good governance (Oloo and Kamungi, 2012).

Also, ICT tools are continuously being utilised by online social movements in Nigeria as means of facilitating mass mobilization of people at both national and international levels to demand social change in certain areas of life. A case in point here is the 'Bringbackourgirls' Movements that resulted in global online campaigns and mass protests calling for the release of over 234 female students of Girls Government Secondary School, Chibok in Borno State, North East Nigeria, kidnapped by the Boko Haram terrorist group since April 2014 (Okoro, 2014; Otuchikere et al., 2014). The ongoing demand for the release of the girls across different cities in Nigeria and in some other parts of the world is made possible through a high level of interconnectivity facilitated by the ICT resources such as Facebook, Twitter, Youtube and Hi5, amongst others. Similarly, different online social movements across the country used ICT resources to decry the poor handling of the Rivers State House of Assembly crisis in 2013 by the former Commissioner of Police for the State, Mr. Joseph Mbu (Adepegba, 2013; Aturu, 2013). The accumulated effect of the criticisms levelled against the State Police Command later resulted in his transfer from Rivers State to the Federal Capital Territory (FCT) by the then Inspector General of Police, Muhammed Abubarkar. In a similar vein, the heavy deployment of military personnel in the 2014 Ekiti and Osun States' gubernatorial elections have been widely condemned by different social movements, who registered their displeasure with this new trend via ICT tools. Oloo and Kamungi (2012) have equally articulated that ICT has played a critical role in mobilising popular protest against perceived injustices or inequality and to demand better governance.

\section{Challenges of Online Social Movements in Nigeria}

From the preceding discourse, it is crystal clear that online social movements are gradually and increasingly influencing state affairs in Nigeria. In spite of this achievement, however, the extent of online activism in the country is not yet holistic in term of the level of 
inclusiveness. The effectiveness of online social movements in Nigeria may be threatened in the near future by three major factors:

Poverty: as a result of the acute poverty that is being experienced by the majority of Nigerians, access to ICT resources (such as computers, Internet-enabled mobile phones, or tablets) that can facilitate online discourse about public affairs is still grossly low; such facilities are not generally owned by Nigerians. This digital divide in Nigeria between the 'haves' and the 'have-nots', fostered by poverty (Akanbi and Akanbi, 2012), sometimes indirectly impinges on the quality of engagement on online public domain. In some cases the people who are directly affected by certain conditions and are willing to share their experience in an online public domain may not be able to add their voice to online discourse that directly concern them, because of a lack of access to ICT-enabled social media platforms. Consequently, the true nature of their condition(s) may not be accurately presented or may be exaggerated in some cases. However, this problem is not peculiar to Nigeria, other countries like Iran and China are also experiencing physical access gaps due to factors such as lowspeed Internet and limited access (Ameripour, Nicholson and Newman, 2010; Cross 2010).

Skills Gap: the activity of online social movements in Nigeria is presently skewed towards a particular group of people among the Nigerian populace. There is a sharp division in terms of age and location of residence with regard to the utilisation of ICT resources among Nigerians (Obayelu and Ogunlade, 2006). While young people have enthusiastically embraced the use of social media platforms, the majority of older Nigerians are still lagging behind in the adoption of these ICT tools. Similarly, the use of ICT resources is more popular among urban dwellers compared with their rural counterparts (Yau', 2002). The implication of this is that members of online social movements in Nigeria are generally dominated by young people residing in urban areas. Hence, it is the opinion of this group of people that is typically heard or seen on the various social media platforms dealing with public issues. ICT usage, according to Ghobadi and Ghobadi (2013), is largely linked to the demographic characteristics of users and technical connections

Vested Interests: the vibrancy or effectiveness of online social movements in Nigeria may also be threatened by vested interests in the near future. Unless the 'leaders' of online social movements are continuously accountable and maintain their integrity, such forums could be hijacked by self-serving politicians for their own selfish political gains. Needless to say, if this is not properly contained, it would certainly be counter-productive to online social movements' demands for good governance. A recent trend in the activities of online social movement is for politicians to commission some youths to create platforms on the social media, to counter the activities of online social movements considered to be working against their interests. Indeed, different pressure groups and watchdogs in Nigeria have occasionally been accused of compromising their cherished ideals after being pressurised and/or financially induced by some politicians in the country (Ike, 2008).

\section{Conclusion}

This paper has critically reviewed the pivotal role that the Information and Communication Technology (ICT) played in the emergence of online social movements in Nigeria and how they are deploying different ICT resources, particularly social media platforms and other networking sites, to mobilise for the principle of good governance in state affairs. Today, the 
actions of the government and public officials at both the federal and state levels are directly and indirectly being influenced by online social movements in the country. Therefore, to the extent that online social movements are adopting ICT resources to demand accountability and transparency in government, to bridge the gap between the citizenry and government, to debate public policies, to promote management's effectiveness and efficiency, and to decry social ills, they are clearly veritable tools with significant potential and actual roles in the consolidation of good governance in Nigeria; the significance of these roles cannot be overemphasised.

\section{References}

Adepegba, A. (2013, July 28). Police keep mum on Rivers. The Punch.

Adeyemo, S. A. (2010). The impact of Information and Communication Technologies (ICT) on teaching and learning of physics. International Journal of Educational Research and Technology, 1(1), 48-59.

Akanbi, B. E. and Akanbi, C. O. (2012). Bridging the digital divide and the impact on poverty in Nigeria. Computing, Information Systems \& Development Informatics, $3(4), 81-87$.

Akanle O., Adebayo, K. and Olorunlana, A. (2014). Fuel subsidy in Nigeria: contexts of governance and social protest. International Journal of Sociology and Social Policy, 34(1/2), 88-106.

Akasike, C. (2012, October 18). Court reminds 13 suspects in prison. The Punch.

Akhigbe, N. (2014, January 21). Same-Sex marriage: Nigeria Vs Western power. Business Day.

Akinkuotu, E. (2015, January 19). Jonathan is promoting corruption - Keyamo. The Punch.

Ameripour, A., Nicholson, B. and Newman, M. (2010). Conviviality of Internet social networks: An exploratory study of Internet campaigns in Iran. Journal of Information Technology, 25, 244-257.

Aturu, B. (2013, July 13). Rivers state crisis: issues, sense and nonsense. Vanguard.

Bohler-Muller, N. and van der Merwe, C. (2011). The potential of social media to socio political change on the African continent. Africa Institute of South Africa Briefing, 46.

Cardoso, G. and Neto, P.P. (2004). Mass media driven mobilization and online protest (ICTs and the pro-east Timor movement in Portugal. In W.V. De Donk, B.D. Loader, P.G Nixon and D. Rutch (Eds.), Cyberprotest: new media, citizens and social movements (pp. 129-143). Routledge, London.

Castells, M. (1997). The rise of the network society - the Information Age: economy, society and culture. Oxford: Blackwell.

Cortright, D. (2007). The movement against war in Iraq. Nonviolent social change: the bulletin of the Manchester college peace studies institute. 
Cragun, T. and Cragun, D. (2006). Introduction to sociology. http://en.wikibooks.org/wiki/ Introduction_to_Sociology

Cross, K. (2010). Why Iran's green movement faltered: The limits of information technology in a rentier state. SAIS Review, 30, 169-187.

Della Porta, D. and Mosca, L. (2005). Global-net for global movements? A network of Networks for a movement of movements. Journal of Public Policy, 25(1), 165-190.

Diani, M. (2000). Social movement networks virtual and real. Information, Communication and Society 3(3), 388-391.

Ekpu, R. (2009, December 21). Ten years of faltering steps. Newswatch.

Gamson, W. A. (1982). Encounters with unjust authorities. Homewood, IL: Dorsey.

Gbadebo, B. (2014, November 27). Jonathan promoting corruption - Obasanjo. Leadership.

Geser, H. (2001). On the functions and consequences of the Internet for social movements and voluntary associations. In Sociology in Switzerland: social movements, pressure groups and political parties (Soziologisches Institut der Universität Zürich: Zurich). University of Zurich online. Retrieved August 5, 2014 from http:// socio.ch/movpar/t_hgeser3.pdf

Ghobadi, S. And Clegg, S. (2014). These days will never be forgotten...: a critical mass approach to online activism. Information and Organization, 25(1), 52-71.

Ghobadi, S. and Ghobadi, S. (2013). How access gaps interact and shape digital divide: a cognitive investigation behaviour and information technology. http:// www.tandfonline.com/doi/abs/10.1080/0144929x.2013.833650

Gracia, I. (2011). Social media-integration: theory-model. http://www.socialmediatoday.com/ isragracia

Haase-Reed, A. Kushin, M. and Koeppel, T. (2007). Framing the ELF: an exploration of media representation and self-representation of a social movement organization. Conference Papers - National Communication Association.

Hogan, B. and Quan-Haase, A. (2010). Persistence and China in social media. Bulletin of Science, Technology \& Society (BSTS), 30, 309-315.

Ibeanu, O. and Momoh, A. (2008). State responsiveness to public security needs: the politics of security decision-making (Nigeria country study). Conflict, Security and Development Group, 14.

Ibrahim, B. H. (2013). Nigerians usage of facebook during 2012 Occupy Nigeria protests: between networked and real public spheres. Research 5(7), 55-64.

Ike, O. I. (2008). Corruption: threat to democracy and market economy - the case of Nigeria. Paper presented at the international symposium on Nachaltigikeit (sustainability) Als Guetermaerkten, held at Bank Fuer Kreditanstalt und Wiederaufban (kfw) Frankfurt/ Main Germany, 29th-30th May, 2008.

Kahn, R. and Kellner, D. (2004). New media and Internet activism: from the 'battle of Seattle' to blogging. New Media and Society, 6(1), 87-95. 
Kaplan, R. and Haenlein, M. (2010). Users of the world, unite! The challenges and opportunities of social media. Business Horizons, 53(1), 59-68.

Langman, L. (2005). From virtual public spheres to global justice: a critical theory of Internet worked social movements. Sociological Theory, 23(1), 42-74.

Latinwo, R. (2013, January 30). N27bn pension thief rearrested after outcry. The Punch.

Norris, P. (2001). New social movements, protest politics, and the Internet in democratic Phoenix: political activism worldwide. Harvard University Press: Cambridge.

Nwabasha, I. (2015, May 29). How social media shapes today's election. Peoples' Daily.

Obayelu, A. E. and Ogunlade, I. (2006). Analysis of the uses of information and communication technology for gender empowerment and sustainable poverty alleviation in Nigeria. International Journal of Education and Development Using Information and Communication Technology, 2(3), 45-69.

Oberschall, A. (1973). Social conflict and social movements. Englewood Cliffs, NJ: PrenticeHall.

Odock, C. N. (2006). Democracy and good governance. NOUN: Lagos.

Ogala, E. (2014, April 19). Police claims arrest of officers caught on camera brutalizing women in Lagos. Sahara Reporter.

Ojedokun, U. A. (2010). Cyber crime and changing lifestyle among students of some selected universities in south western Nigeria. Unpublished M.Sc. dissertation, University of Ibadan, Nigeria.

Ojeme, V. (2014, May 17). NIS recruitment: please, forgive me, Abba Moro begs Nigerians. Vanguard.

Okoro E (2014, May 11) Global uproar over missing Chibok girls. Daily Independent.

Oloo, A. and Kamungi, P. (2012). Navigating the role of ICTs in good governance in Kenya (2008-2012). Africa Peace Forum.

Oseni, A. L. (2015, April 4). Social media revolutionises Nigerian election. News Diary Online.

Otuchikere, C., Agba, G. and Odemwingie, E. (2014, May 5). Chibok girls: police disperse protesters in Abuja. Leadership.

Owuamanam, J. (2013, October 1). Taraba crisis: Suntai seeks out-of-court settlement. The Punch.

Petras, J. (2011). Egypt: social movements, the CIA and Mossad. http:// canadiandimension.com/articles/3725/

Roberts, B. (2009). Beyond the networked public sphere: politics, participation and technics in web 2.0. Fibreculture journal, 14. http://fourteen.fibreculturejournal.org/fcj-093beyond-the-networked-public-sphere-politics-participation-and-technics-in-web-2-0/ http://www.fibreculturejournal.org/fc 
Salmon, C. T., Fernandez, L. and Post, L. A. (2010). Mobilizing public will across borders: roles and functions of communication processes and technologies. Journal of Borderlands Studies, 25 (3\&4), 159-170.

Scott, A. and Street, J. (2001). From media politics to e-protest? The use of popular culture and new media in parties and social movements. In F. Webster (Ed.), Culture and politics in the information age, A New Politics? London: Routledge.

Shifter, M. and Caivano, J. (2009). Forward' in inter-American dialogue, media and governance: a reform agenda in Latin America and the Caribbean. Washington D.C.: Inter-American Dialogue.

Snow, S., Soule, A. and Kriesi, H. (2004). The Blackwell companion to social movements. Malden, MA: Blackwell Publishing Ltd..

Soni, D. (2013, August 28). Taraba govt. crisis deepens. Vanguard.

Soriwei, F. and Adepegba, A. (2014, March 21). Moro, NIS boss fought over immigration recruitment-investigation. The Punch.

Spier, S. (2011). The impact of ICT-based social media on collective action-difference in degree or difference in kind? Humboldt University Zu Berlin.

Stanko, J. (2013). Social media, political upheaval, and state control. Unpublished M. A. Dissertation, Washington University.

Stepanova, E. (2011). The role of Information and Communication Technologies in the "Arab spring": implications beyond the region. Ponars Eurasia.

Stolley, K. S. (2005). The basics of sociology. The Greenwood Press.

The Nation (2013, August 28). Suntai's 'return to work' sparks crisis in Taraba. (Newspaper article).

The Punch (2014, April 16). NIS recruitment tragedy: victims await FG's compensation. (Newspaper article).

The Punch (2014, January 13). N225m car scandal: presidential panel indicts Oduah. (Newspaper article).

Titus-Fannie A., Akpan, C. S. and Tarnogo, M. S. (2013). An assessment of the utilisation of social media mobilisation of Nigerian youths in 2011 general elections. A case study of youths in Benue State. Journal of Humanities and Social Sciences, 6(5), 32-44.

Ugwu E (2013, March 22). Abia lauds Police for arresting gang rapists. This Day Live.

United Nations Development Programme (1997). Governance for sustainable human development. New York, UNDP.

Vanguard (2013, August 28). Crisis in Taraba over Suntai. (Newspaper article).

Wall, M. (2007). Social movements and email: expressions of online identity in the globalisation protests. New Media and Society, 9(2), 258-277.

Wasserman, H. (2005). Connecting African activism with global networks: ICTs and South African social movements. Africa Development 30 (1 \& 2), 163-182. 
Wilson, J. (2012). One to another: the occupy movement challenges the media. http:// www.opendemocracy.net/johnwilson/one-to-another occupy-movementchallengesmedia

World Bank (1989). Sub-Saharan Africa: from crisis to sustainable growth. Washington, DC: World Bank.

Ya'u, Y. Z. (2002). Confronting the digital divide: an interrogation of the African initiatives at bridging the gap. http://www.codesria.org/Links/conferences/Nepad/yau.pdf 